\title{
Transfusion-Transmissible Infections among Voluntary Blood Donors at Debre Tabor Blood Bank, North West Ethiopia: A Three Years Retrospective Study
}

Berhanu $\mathrm{S}^{1 *}$, Abebaw $\mathrm{S}^{2}$ and Digissie $\mathrm{A}^{2}$

${ }^{1}$ Department of Epidemiology, Jimma University, Institute of health, Ethiopia

${ }^{2}$ Debre Tabor University, Ethiopia

\begin{abstract}
Background: Blood is one of the integral components of body constituents; transfusion of blood and blood products is a lifesaving intervention and benefits numerous patients worldwide. Even if blood donation has invaluable benefits, it carries the risk of transmitting the life- threatening infectious agents. The prevalence of transfusion-transmissible infections (TTI) in blood donations ranges from $0.002 \%$ in high-income countries to $0.85 \%$ in low income countries for HIV. The aim of this study is to assess transfusion transmissible infections among voluntary blood donors at Debre Tabor blood bank.
\end{abstract}

Method: An institutional based cross-sectional study design was conducted among voluntary blood donors at Debre Tabor blood bank from September 2014 - August 2017. All blood donors were included in the study and checklist was used to extract data from records. Epi-Data version 3.1 and SPSS version 20 were used to data entry and analysis respectively. Descriptive analysis was conducted to describe socio demographic, blood type related and blood borne pathogens. Finally, tables, figure and narration were used to display the results.

Result: A total of 7255 blood units were collected during the study period. The mean age of donors was $21.16 \pm$ SD 4.805 years, the mean weight $57.96 \pm 7.25 \mathrm{Kg}$ and males constitute $65.2 \%$ (4734). At least one of the blood borne pathogens were detected among $333(4.6 \%)$ of blood units. The overall positivity rate for HIV, HBV, HCV and Syphilis was $30(0.41 \%), 200(2.76 \%), 49(0.68 \%)$ and $54(0.74 \%)$ respectively.

Conclusion: The prevalence of blood borne pathogens among voluntary blood donors was high.

Keyword: Blood donation; Blood borne pathogens; Debre tabor town; Ethiopia

\section{Introduction}

Blood is one of the integral components of body constituents. Transfusion of blood and blood products is a lifesaving intervention and benefits numerous patients worldwide [1]. It is an invaluable, life-sustaining fluid. Without a sufficient amount, the cells of the human body could not receive adequate oxygen and nutrients they need to survive. Large volume of blood could be lost because of numerously varying serious conditions such as road traffic accidents and hemorrhagic conditions. Because of these, blood transfusion is considered as an integral and essential element of a health care system [2]. Blood donation is philanthropic deed in which the blood of a healthy person had been drawn voluntarily for the purpose of transfusion. The donated blood can be life saving for individuals who have lost large amounts of blood because of different incidents [3]. It is a procedure of collecting blood from a screened person who must follow the strict guidelines in the country where they lives. There are several types of blood donation: whole blood, platelets, plasma, and double red cells. The main cell in an individual's blood is red blood cell (also called erythrocytes) [4]. World Health Organization (WHO) recommends countries to focus on young people to achieve $100 \%$ nonremunerated voluntary blood donation by 2020 . It also recommends that all countries should be self-sufficient in all blood products and that all blood donation should be voluntary, anonymous, and nonremunerated [5]. Screening for transfusion-transmissible infections to exclude blood donations at risk of transmitting infection from donors to recipients is a critical part of the process of ensuring that transfusion is as safe as possible. Blood transfusion services should therefore establish efficient systems to ensure that all donated blood is correctly screened for specific TTIs and that only non-reactive blood and blood components are released for clinical use and manufacturing purposes [6].

Screening of all blood donations should be mandatory for HIV1 and HIV-2: screening for either a combination of HIV antigenantibody or HIV antibodies, Hepatitis B: screening for hepatitis B surface antigen (HBsAg), Hepatitis C: screening for either a combination of HCV antigen antibody or HCV antibodies and Syphilis (Treponema pallidum): screening for specific treponemal antibodies [7]. The provision of safe and efficacious blood and blood components for transfusion or manufacturing purposes involves a number of processes, from the selection of blood donors and the collection, processing and screening of blood, to the testing of patient samples, the issue of compatible blood and its administration to the patient. There is a risk of error at each stage of the process in this "transfusion chain". A failure at any stage can have serious implications for the recipients of blood and blood products. Thus, while blood transfusion can be life-saving, there are associated risks, particularly the transmission of blood-borne infections [6]. A lower prevalence of TTIs in the donor

*Corresponding author: Solomon Berhanu, Department of Epidemiology, Jimma University, Ethiopia, Tel: 251932442238; E-mail: Solo.berhanu@gmail.com

Received October 31, 2018; Accepted December 18, 2018; Published December 26, 2018

Citation: Berhanu S, Abebaw S, Digissie A (2018) Transfusion-Transmissible Infections among Voluntary Blood Donors at Debre Tabor Blood Bank, North West Ethiopia: A Three Years Retrospective Study. Health Care Current Reviews 6: 236. doi: 10.4172/2375-4273.1000236

Copyright: ( 2018 Berhanu S, et al. This is an open-access article distributed under the terms of the Creative Commons Attribution License, which permits unrestricted use, distribution, and reproduction in any medium, provided the original author and source are credited. 
Citation: Berhanu S, Abebaw S, Digissie A (2018) Transfusion-Transmissible Infections among Voluntary Blood Donors at Debre Tabor Blood Bank, North West Ethiopia: A Three Years Retrospective Study. Health Care Current Reviews 6: 236. doi: 10.4172/2375-4273.1000236

population reduces the discard of donated blood and hence results in improved efficiency and use of resources [7].

The prevalence of transfusion-transmissible infections (TTI) in blood donations ranges from $0.002 \%$ in high-income countries to $0.85 \%$ in low income countries for HIV. Hepatitis B Virus (HBV) infections prevalence among blood donations reaches as high as $6 \%$ in low-income countries. Therefore, transmission of TTI is preventable by establishing an adequate supply of safe blood through voluntary blood donation practices [8]. An unsafe blood transfusion is very costly both from human and economic point of view. Morbidity and mortality resulting from the transfusion of infected blood have far-reaching consequences, not only for the recipients themselves but also for their families, their communities and the wider society $[9,10]$. The cost includes increase requirement for medical care, higher level of dependency, loss of productive labor force and placing heavy burden on already overstretched health and social services on national economy $[9,11]$. Keeping in mind the grave consequences of infections to restrain the transmission to minimum is very important to remain vigilant about the possible spread of these infections [12]. Thus, screening for TTI's is essential for blood transfusion safely and in extension for protecting human life [13]. Therefore, the aim of the current study is to assessment transfusion-transmissible infections among voluntary blood donors at Debre Tabor blood bank, northwest Ethiopia.

\section{Method and Materials}

\section{Study area and period}

The study was conducted in Debre Tabor Town, Amhara Region, Ethiopia. The town were located $666 \mathrm{Km}$ away from Addis Ababa, the capital city of Ethiopia in North Western direction. The study was conducted from September 2014-August 2017.

\section{Study design and population}

An institutional based cross sectional study among voluntary blood donors was conducted. Voluntary blood donors who donate blood during 2014-2017 from registers were included in the study.

\section{Sample size and sampling technique}

All voluntary blood donors between 2014-2017 were considered for the study. A total of 7255 blood donors from the register constitute the sample for the study.

\section{Variables}

For socio demographic characteristics, sex and age were considered. For blood type related, ABO blood type, RH Factors and volume of donation were considered. And for blood borne pathogens, HIV, HBV, $\mathrm{HCV}$ and Syphilis were included.

\section{Data collection technique and procedure}

The district blood bank follows the guideline of the blood bank center and exclusion criteria; individuals who had a history of febrile or debilitating illness, ages below 18 or over 65 years, pregnant or lactating, body weight lower than $45 \mathrm{~kg}$ and hemoglobin level of 12.5 $\mathrm{g} / \mathrm{dL}$ or lower were excluded from donation. For those donors list, structured checklist was used to extract data from their records of medical and socio-demographic data.

\section{Data processing and analysis}

The collected data were checked for its completeness manually, data cleaning and entry were done using Epi-Data version 3.1. The entered data were exported to SPSS version 21 for data analysis. Data editing, coding, checking and organization were done to transform the data into format suitable for farther analysis. Descriptive analysis was conducted to describe socio demographic, blood type related and blood borne pathogens; Continuous variables were represented as Mean \pm SD. Finally, tables, figure and narration were used to display the results.

\section{Ethical consideration}

The study was carried out after getting approval from the ethical clearance committee of Debre Tabor University and District blood Bank Office.

\section{Result}

\section{Characteristics of voluntary blood donors}

The study considers three consecutive years, (September 2014August 2015, September 2015- August 2016 \& September 2016- August 2017 G.C) voluntary blood donations at Debre Tabor Blood Bank. From the total 7255 blood units collected during the study period, the mean age of donors was $21.16 \pm$ SD 4.805 years, the mean weight 57.96 $\pm 7.25 \mathrm{Kg}$ and males constitute 65.2\% (4734) (Table 1).

\section{Trend of blood donation}

The number of voluntary blood donors was increased from year to year in the study period (Figure 1).

\section{Prevalence of blood borne pathogens}

Among the total 7255 blood units collected, at least one of the blood borne pathogens were detected among 333 (4.6\%) of blood units. The overall positivity rate for HIV, HBV, HCV and Syphilis was 30 (0.41\%), $200(2.76 \%), 49(0.68 \%)$ and $54(0.74 \%)$ respectively (Table 2). The distribution of blood pathogens in the different blood group and age categories were summarized in Table 3 . With respect to absolute number, the study identifies higher number of the distribution of the different types of blood borne pathogens among $\mathrm{RH}$ positives, $\mathrm{O}$ blood group, and among age category of 18-24 year of age.

\begin{tabular}{|c|c|c|c|}
\hline \multirow{3}{*}{ Sex } & & No. & Percent \\
\hline & Male & 4734 & 65.3 \\
\hline & Female & 2521 & 34.7 \\
\hline \multirow{3}{*}{ Age } & $18-24$ & 6214 & 85.6 \\
\hline & $24-44$ & 983 & 13.5 \\
\hline & $45-65$ & 58 & .8 \\
\hline \multirow{4}{*}{ Blood Group } & A & 2188 & 30.1 \\
\hline & B & 1721 & 23.7 \\
\hline & $A B$ & 441 & 6.1 \\
\hline & O & 2840 & 39.1 \\
\hline \multirow{2}{*}{$\mathbf{R H}^{*}$} & Positive & 6612 & 91.0 \\
\hline & Negative & 578 & 8.0 \\
\hline \multirow{3}{*}{$\begin{array}{c}\text { Volume of } \\
\text { donated bloods }\end{array}$} & $350 \mathrm{ml}$ & 6898 & 95.1 \\
\hline & $400 \mathrm{ml}$ & 254 & 3.5 \\
\hline & $250 \mathrm{ml}$ & 103 & 1.4 \\
\hline
\end{tabular}

* 65 observations were missed observations.

Table 1: Characteristics of voluntary blood donors in Debre Tabour Town who donates bloods from September 2014-August 2017. 
Citation: Berhanu S, Abebaw S, Digissie A (2018) Transfusion-Transmissible Infections among Voluntary Blood Donors at Debre Tabor Blood Bank, North West Ethiopia: A Three Years Retrospective Study. Health Care Current Reviews 6: 236. doi: 10.4172/2375-4273.1000236

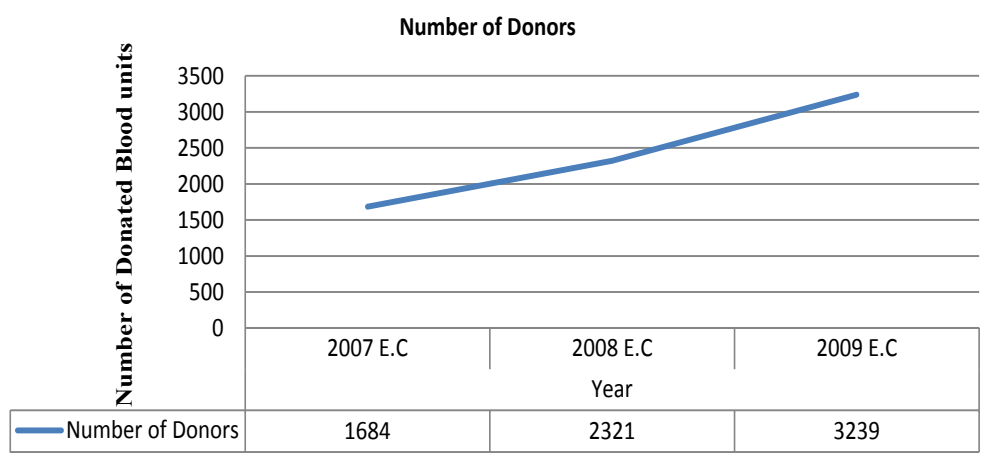

Figure 1: Trend of Blood donation among Debre Tabor town blood donors from September 2014-August 2017.

\begin{tabular}{|c|c|c|c|c|c|c|c|c|c|c|c|c|c|c|}
\hline \multirow{2}{*}{\multicolumn{3}{|c|}{ Year of Blood Donation }} & \multicolumn{3}{|c|}{ HIV status } & \multicolumn{3}{|c|}{ Hepatitis B status } & \multicolumn{3}{|c|}{ Hepatitis C status } & \multicolumn{3}{|c|}{ Syphilis status } \\
\hline & & & No. & $\%$ & Total & No. & $\%$ & Total & No. & $\%$ & Total & No. & $\%$ & Total \\
\hline \multirow{3}{*}{ 2007E.0 } & \multirow[t]{2}{*}{ Sex of Donor } & Male & 10 & $0.94 \%$ & 1067 & 37 & $3.00 \%$ & 1067 & 6 & $0.56 \%$ & 1067 & 8 & $0.75 \%$ & 1067 \\
\hline & & Female & 2 & $0.32 \%$ & 617 & 10 & $2.00 \%$ & 617 & 5 & $0.81 \%$ & 617 & 2 & $0.32 \%$ & 617 \\
\hline & Total & & 12 & $0.71 \%$ & 1684 & 47 & $3.00 \%$ & 1684 & 11 & $0.65 \%$ & 1684 & 10 & $0.59 \%$ & 1684 \\
\hline \multirow{4}{*}{ 2008E.0 } & \multirow{2}{*}{ Sex of Donor } & Male & 5 & $0.33 \%$ & 1535 & 55 & $4.00 \%$ & 1535 & 5 & $0.33 \%$ & 1535 & 12 & $0.78 \%$ & 1535 \\
\hline & & Female & 2 & $0.25 \%$ & 786 & 5 & $0.64 \%$ & 786 & 3 & $0.38 \%$ & 786 & 9 & $1.00 \%$ & 786 \\
\hline & Total & & 7 & $0.30 \%$ & 2321 & 60 & $3.00 \%$ & 2321 & 8 & $0.34 \%$ & 2321 & 21 & $0.90 \%$ & 2321 \\
\hline & \multirow{2}{*}{ Sex of Donor } & Male & 8 & $0.38 \%$ & 2132 & 67 & $3.00 \%$ & 2132 & 18 & $0.84 \%$ & 2132 & 17 & $0.80 \%$ & 2132 \\
\hline \multirow{4}{*}{ 2009E.c } & & Female & 3 & $0.27 \%$ & 1118 & 26 & $2.00 \%$ & 1118 & 12 & $1.00 \%$ & 1118 & 6 & $0.54 \%$ & 1118 \\
\hline & Total & & 11 & $0.34 \%$ & 3250 & 93 & $3.00 \%$ & 3250 & 30 & $0.92 \%$ & 3250 & 23 & $0.71 \%$ & 3250 \\
\hline & \multirow{2}{*}{ Sex of Donor } & Male & 23 & $0.49 \%$ & 4734 & 159 & $3.00 \%$ & 4734 & 29 & $0.61 \%$ & 4734 & 37 & $0.78 \%$ & 4734 \\
\hline & & Female & 7 & $0.28 \%$ & 2521 & 41 & $2.00 \%$ & 2521 & 20 & $0.79 \%$ & 2521 & 17 & $0.67 \%$ & 2521 \\
\hline Total & Total & & 30 & $0.41 \%$ & 7255 & 200 & $3.00 \%$ & 7255 & 49 & $0.68 \%$ & 7255 & 54 & $0.74 \%$ & 7255 \\
\hline
\end{tabular}

Table 2: Distribution of Blood Borne Pathogens by year and sex among Debre Tabor town blood donors from September 2014-August 2017.

\begin{tabular}{|c|c|c|c|c|c|c|c|c|c|c|c|c|c|}
\hline \multirow[b]{2}{*}{ R1-1 status } & \multirow[b]{2}{*}{ Positive } & \multicolumn{2}{|c|}{$\begin{array}{l}\text { My status } \\
\text { Yes No }\end{array}$} & \multirow{2}{*}{$\begin{array}{l}\text { Total } \\
6612\end{array}$} & \multicolumn{2}{|c|}{$\begin{array}{c}\text { Hepatitis B status } \\
\text { Yes No }\end{array}$} & \multirow{2}{*}{$\begin{array}{l}\text { Total } \\
6612\end{array}$} & \multicolumn{2}{|c|}{$\begin{array}{c}\text { Hepatitis C status } \\
\text { Yes No }\end{array}$} & \multirow{2}{*}{$\begin{array}{l}\text { Total } \\
6612\end{array}$} & \multicolumn{2}{|c|}{$\begin{array}{c}\text { Syphilis status Yes } \\
\text { No }\end{array}$} & \multirow{2}{*}{$\begin{array}{l}\text { Total } \\
6612\end{array}$} \\
\hline & & 29 & 6583 & & 175 & 6437 & & 41 & 6571 & & 50 & 6562 & \\
\hline & Negative & 1 & 577 & 578 & 22 & 556 & 578 & 8 & 570 & 578 & 3 & 575 & 578 \\
\hline Total & & 30 & 7160 & 7190 & 197 & 6993 & 7190 & 49 & 7141 & 7190 & 53 & 7137 & 7190 \\
\hline Blood & A & 6 & 2182 & 2188 & 57 & 2131 & 2188 & 13 & 2175 & 2188 & 17 & 2171 & 2188 \\
\hline \multirow[t]{3}{*}{ Type } & B & 7 & 1714 & 1721 & 51 & 1670 & 1721 & 12 & 1709 & 1721 & 15 & 1706 & 1721 \\
\hline & $A B$ & 2 & 439 & 441 & 8 & 433 & 441 & 6 & 435 & 441 & 2 & 439 & 441 \\
\hline & 0 & 15 & 2825 & 2840 & 81 & 2759 & 2840 & 18 & 2822 & 2840 & 19 & 2821 & 2840 \\
\hline Total & & 30 & 7160 & 7190 & 197 & 6993 & 7190 & 49 & 7141 & 7190 & 53 & 7137 & 7190 \\
\hline \multirow{3}{*}{ Age category } & $18-24$ & 25 & 6189 & 6214 & 156 & 6058 & 6214 & 40 & 6174 & 6214 & 25 & 6189 & 6214 \\
\hline & $25-44$ & 4 & 979 & 983 & 43 & 940 & 983 & 9 & 974 & 983 & 17 & 966 & 983 \\
\hline & $45-65$ & 1 & 57 & 58 & 1 & 57 & 58 & 0 & 58 & 58 & 12 & 46 & 58 \\
\hline Total & & 30 & 7225 & 7255 & 200 & 7055 & 7255 & 49 & 7206 & 7255 & 54 & 7201 & 7255 \\
\hline
\end{tabular}

Table 3: Distribution of Blood Borne Pathogens by blood groups and age category among Debre Tabor town blood donors from September $2014-$ August 2017.

\section{Discussion}

The current study focuses on the assessment and description of the four common blood borne pathogens among voluntary blood donor in the study area. The study identifies that, there is no regular increment or decrement pattern of prevalence of blood borne pathogens within the three consecutive year periods. From the total voluntary blood donors, male have the higher contribution, constitute around two third. The finding was comparable with studies done in Ethiopian and sub-Saharan Africa [14-16] and this might be due to knowledge and attitude difference between the two sex, due to physiologic difference (menstruation cycle and birth related issues) that, females were less participate in voluntary blood donation. Despite the fact that males were more in the donor pool of this study, females were comparatively high when compared with female involvement in blood donation in other studies in Ethiopia and Nigeria $[17,18]$. This might be due to the fact that the present study comprised of voluntary donors while the other Ethiopian and Nigerian studies comprised of voluntary, replacement and commercial donors. Females have been reported to donate more owing to altruism rather than remunerated reasons. The age group of 18 - 24 years took the donation than other age categories and the finding is comparable with a study done in Eritrea [15]. The higher contribution of 18-24 years of age group might be due to fear that, as age increases the population might perceive that donating blood may cause problem on them. When we see the distribution of blood groups among the total donated bloods, O type was the highest 
Citation: Berhanu S, Abebaw S, Digissie A (2018) Transfusion-Transmissible Infections among Voluntary Blood Donors at Debre Tabor Blood Bank, North West Ethiopia: A Three Years Retrospective Study. Health Care Current Reviews 6: 236. doi: 10.4172/2375-4273.1000236

followed by A, B and AB. The finding is in accordance with other studies done in Ethiopia and sub-Saharan Africa [17,19,20]. From the blood groups, Blood group $\mathrm{AB}$ only constitutes six percent and the district might face shortage of the specified blood group type and the same is true for the RH factor that, $\mathrm{RH}$ negative was only eight percent from the total donation.

The study identified that, 7255 blood units were collected in the tree consecutive years and from them, $4.6 \%$ were have at least one of the blood borne pathogens. The finding is lower as compared to a study done in Wollaita Sodo, South Ethiopia [14] but slight higher as compared to study done in Eritrea and South Ethiopia [15,16]. The observed difference might be because of the actual differences in population risks or strictness and effectiveness of the procedures followed of blood collection process. Among the different blood borne pathogens, the prevalence of HIV was $0.41 \%$, which is lower as compared to studies done in Wollaita Sodo and South Ethiopia (14) but it shows slightly higher rate than study done in Eritrea and South Ethiopia $[15,16]$. This might also be due to the actual differences in population risks or strictness and effectiveness of the procedures followed of blood collection process. The prevalence of HBV among the collected blood units was $2.76 \%$, which is lower as compared to studies done in Wollaita Sodo, Ethiopia and South West Ethiopia $[14,16]$ and higher as compared to a study done in Eritrea [15]. The other finding of the study is on $\mathrm{HCV}$ and the prevalence of $\mathrm{HCV}$ among the collected blood units was $0.68 \%$. which is comparable with a study done in Eritrea [15], Lower as compared to a study done Wollaita Sodo, Ethiopia [14] and higher as compared to a study done in south east Ethiopia [16]. The current study also identified that, the prevalence of Syphilis among the collected blood units was $0.74 \%$, which is lower as compared to a study done in Wolliata Sodo, Ethiopia [14] but higher as compared to studies done in South east Ethiopia and Eritrea $[15,16]$.

\section{Limitation}

Since the study considers secondary data, only few variables were included in the study. Due to this, the study might miss different variables with significant information for giving clue on blood borne pathogens.

\section{Conclusion}

As compared to different studies, the prevalence rate of blood borne pathogens in the study setting was high. From voluntary blood donations, due to the pathogens, up to $5 \%$ of blood units were not used for the desired purpose.

\section{References}

1. Lathamani K, Bhaktha G, Nayak S (2013) Prevalence of HIV, HCV, HBV and Syphilis in blood donors among the Dakshina Kannada district, India. Int J Curr Microbiol App Sci 2: 249-252.
2. Amatya M (2013) knowledge, attitude and practice of blood donation among students of different colleges of Kathmandu, Nepal. International J Pharmaceutical and Biological Archives 4: 424-428.

3. Olubiyi SK, Babalola FR, Olubiyi MV, Umar NJ, Ibraheem MA (2014) Knowledge, attitudes and practices of blood donation among adults in AdoEkiti, Nigeria. Sky J Medicine and Medical Sciences 2: 052-057.

4. Muharib F, Marjorie D (2015) The Benefits of Donating Blood

5. who.int/worldblooddonorday/archives/2010/en/

6. Screening Donated Blood for Transfusion $\square$ Transmissible Infections in Nepal, national guideline.

7. WHO recommendation, Screening Donated Blood for Transfusion Transmissible Infections.

8. Centers for disease control and prevention (CDC) report (2011) Progress towards strengthening national blood transfusion services-14 Countries report 2008-2010 60: 1578-1582.

9. World Health Organization (WHO) Blood safety strategy for the African Region Brazzaville, world health organization, Regional Office for Africa.

10. World Health Organization (WHO) Status of blood safety in the WHO African Region: Report of the 2004 Survey WHO Regional Office for Africa, Brazzaville.

11. Murphy MF, Pamphilon DH (2001) Transfusion transmitted infections.

12. Fernandes H, D'souza PF, D'souza PM (2010) Prevalence of transfusion transmitted infections in voluntary and replacement donors. Indian $\mathrm{J}$ Hematol Blood Transfus 26: 89-91.

13. Buseri FI, Muhibi MA, Jeremiah ZA (2009) Sero-epidemiology of transfusion transmissible infectious diseases among blood donors in Osogbo, south-west Nigeria. Blood Transfus 7: 293-299.

14. Bisetegen F, Bekele F, Ageru T, Wada F (2016) Transfusion-transmissible infections among voluntary blood donors at wolaita sodo University teaching referral hospital, South Ethiopia. Can J Infect Dis Med Microbiol pp: 1-6.

15. Siraj N (2018) Seroprevalence of transfusion-transmissible infections among blood donors at national blood transfusion service, Eritrea: A seven year retrospective study. BMC Infect Dis 18: 264

16. Kebede W, Mekonnen Z, Gerbi G, Abebe G (2017) Transfusion-transmissible infection surveillance among blood donors in Southwest Ethiopia: A six years retrospective study. Asian Pacific J Tropical Disease 7: 156-161.

17. Teklemariam Z, Mitiku H, Weldegebrea F (2018) Seroprevalence and trends of transfusion transmitted infections at Harar blood bank in Harari regional state, Eastern Ethiopia: Eight years retrospective study. BMC Hematology 18: 1-24.

18. Okoroiwu H, Okafor I, Asemota E, Okpokam D (2018) Seroprevalence of transfusion transmissible infections (HBV, HCV, syphilis and HIV) among prospective blood donors in a tertiary health care facility in Calabar, Nigeria; an eleven years evaluation. BMC Public Health 18: 645.

19. Okoroiwu H, Okafor I (2018) Demographic characteristics of blood and blood components transfusion recipients and pattern of blood utilization in a tertiary health institution in southern Nigeria. BMC Public Health 18: 16

20. Ndoula ST, Noubiap JJN, Nansseu JRN, Wonkam A (2014) Phenotypic and allelic distribution of the $\mathrm{ABO}$ and Rhesus (D) blood groups in the Cameroonian population. Int J Immunogenet 41: 206-210. 